УДК 784.071.2(477)(092)

\author{
Регеша Наталія Леонідівна \\ доиент кафедри народнопісенного \\ та хорового мистецтва, \\ Київський національний університет \\ культури і мистецтв \\ Киів, Украйна \\ regeshanatalia@ukr.net
}

\title{
ТВОРЧИЙ ДОРОБОК АНАТОЛІЯ АВДІСВСЬКОГО В КОНТЕКСТІ УКРАЇНСЬКОГО ХОРОВОГО МИСТЕЦТВА
}

Статтю присвячено вивченню творчої спадщини відомого українського диригента, композитора та аранжувальника, керівника Національного заслуженого академічного українського народного хору ім. Г. Верьовки - Анатолія Тимофійовича Авдієвського (1933-2016).

Мета статті: дослідити творчий доробок А. Авдієвського в контексті української хорової традиції з урахуванням власної диригентської інтерпретації, етапи творчої діяльності видатного диригента. Метою наукової розвідки $є$ висвітлення художнього світогляду та музично-виконавської естетики у царині національної музнчної культури.

Досягнення мети передбачас вирішення наступних завдань:

- визначити найважливіші віхи творчої біографії А. Авдієвського;

- розглянути творчий доробок диригента, пов'язаний з його роботою у Національному заслуженому академічному українському народному хорі ім. Г. Верьовки;

- дослідити особливості хормейстерського стилю роботи А. Авдісвського.

Методологія дослідження полягає в аналізі композиторського доробку митця з урахуванням диригентсько-винонавського компоненту, в обгрунтуванні специфічних рис його творчості, обумовлених багатоманітністю його діяльності роботи. Наукова новизна роботи передбачає визначення основних принципів індивідуального композиторського стилю А. Авдісвського та його зв'язок 3 національною хоровою традицією. Маестро зумів поєднати фольклорну манеру виконання 3 академічними засадами хорового співу в українській пісенній культурі. Висновки. Творчий доробок композитора характеризусться синтезом фольклорної традиції та сучасних модерних тенденцій, які увібрали риси синкретизму, тобто використання елементів театральності, обрядового дійства та епічно-декламаційних елементів тощо. 
Ключові слова: Анатолій Авдісвський, хормейстерське мистецтво, автентична музична творчість, народний пісенний фольклор.

Регеша Наталия Леонидовна доцент кафедры народнопесенного и хорового искусства, Киевский национальньй университет культуры и искусств, Кийв, Украина

\section{Творческое наследие Анатолия Авдиевского в контекете украинс- кого хорового искусства}

Статья посвящена изучению творческого наследия известного украинского дирижера, композитора и аранжировщика, руководителя Национального заслуженного академического украинского народного хора им. Г. Веревки Анатолия Тимофеевича Авдиевского (1933-2016).

Цель статьи: исследовать творческое наследи А. Авдиевского в контексте украинской хоровой традиции с учетом личной дирижерской интерпретации, этапы творческой деятельности известного дирижера. Целью научной работы является освещение художественного мировоззрения и музыкально-исполнительской эстетики в области национальной музыкальной культуры.

Для достижения цели ставятся следующие задачи:

- обозначить саме важне этапы в творческой биографии А. Авдиевского;

- рассмотреть творческое наследие дирижера, связанное с его работой в Национальном заслуженном академическом украинском народном хоре им. Г. Веревки;

- исследовать особенности хормейстерского стиля работы А. Авдиевского.

Методология исследования заключается в анализе композитерской наработки творческой личности с учетом дирижерско-исполнительного аспекта, в обозначении специфіки его творчества, обусловленых его многогранностью работы. Научная новизна работы предусматривает опредиление основних принципов индивидуального композитерского стиля А. Авдиевского и его свіязь с национальной хоровой традицией. Выводы. Творческая наработка композитора характеризуется синтезом фольклорной традиции и современных модерных тенденций, которые вобрали черты синкретизма, то есть использование элементов театральности, обрядового действия и эпически-декламационных элементов.

Ключевые слова: Анатолий Авдиевский, хормейстерское искусство, аутентичное музыкальное творчество, народный песенный фольклор. 
Rehesha Nataliia, Associate Professor of the Department of Folk Song and Choral Art, Kyiv National University of Culture and Arts, Kyiv, Ukraine

Anatolii Avdiievskyi's creative work in the context of Ukrainian choral art

The article is devoted to the study of the creative heritage of the famous Ukrainian conductor, composer and arranger, leader of G. Veryovka Ukrainian National Honored Academic Folk Choir Anatolii Tymofiiovych Avdiievskyi (1933-2016).

The purpose of the article is to study Anatolii Avdiievskyi's creative work in the context of Ukrainian choral tradition with due consideration of the conductor's own interpretation, stages of creative activity of the famous conductor; to highlight his artistic vision and musical-artistic aesthetics in the sphere of national music culture.

To achieve the objective, the following tasks need to be completed:

- $\quad$ to specify the main milestones of A. Avdiievskyi's biography;

- to consider the conductor's creative work connected with his work at G. Veryovka Ukrainian National Honored Academic Folk Choir;

- to explore the characteristic features of A. Avdiievskyi's choirmaster style.

The research methodology consisted in the analysis of the composer's creative work with due consideration of the conductorial-interpretative component, and justification of the characteristic features of his creative work, conditioned by the diversity of his creative activity. The scientific novelty of the work lies in defining the key principles of A. Avdiievskyi's unique composer's style and its connection with Ukrainian choral tradition. The master managed to combine folk style of performance with academic principles of choral singing in Ukrainian song culture. Conclusions. The composer's creative work is characterized by the synthesis of folk tradition and modern trends, which absorbed features of syncretism, i.e. the use of elements of theatricality, ritual action and epic-declamatory elements etc.

Key words: Anatolii Avdiievskyi, choirmaster art, authentic music creativity, folk song folklore.

Вступ. Незважаючи на несприятливі умови для масового хорового руху, які обумовлені соціокультурними обставинами, де перевага надається субкультурі в засобах масової інформації, відсутність цілеспрямованої культурної стратегії в популяризації національної академічної спадщини, українська традиція хорового співу все ще залишається дієвою. У цьому процесі суттеву роль відіграють різні напрямки трансформації хорового виконавства, що дозволяють йому пристосуватись до реалій сучасного життя та знайти ефективні способи впливу на широку слухацьку аудиторію. 
Основна проблематика української хорової музики розглянута в працях М. Бурбана, А. Гуменюка, С. Людкевича, О. Бенч, А. Лащенка, С. Грици, Н. Горюхіної, О. Козаренка, В. Перепелюка, О. Скопцовоі, О. Таранченко, О. Торби, I. Шатової та ін.

Потреба в хоровому мистецтві обумовлена попитом українського народу, який не дивлячись на процеси глобалізації й уніфікації музичної продукції, зумів зберегти хорове мистецтво в духовному житті нації. Про що свідчить вельми насичена «хорова інфраструктура» сучасного українського суспільства. Підтвердженням цьому може слугувати активний фестивально-хоровий рух в Україні в останні 20 років. До найяскравіших репрезентантів цього процесу можна віднести: Всеукраїнський хоровий конкурс ім. М. Леонтовича, Міжнародний хоровий конкурс імені Павла Муравського, Всеукраїнський конкурс хорового мистецтва імені Лесі Українки в Луцьку, Всеукраїнський конкурс хорової музики імені Д. Січинського в Івано-Франківську, Всеукраїнський фестиваль-конкурс хорового мистецтва, хоровий конкурс імені К. Г. Стеценка, Всеукраїнський фестиваль-конкурс колективів народного хорового співу імені Порфирія Демуцького, міжнародний дитячий хоровий конкурс-фестиваль «Артеківські зорі» (на якому вручається головний приз - «Кубок Авдієвського», як символічна передача традиції від метра до молодих колег) та багато ін. Заснування й успішне проведення численних хорових конкурсів і фестивалів за роки Незалежності України стимулювали активну конкуренцію між колективами та диригентами, сприяли зростанню художнього рівня професійних, народних і аматорських хорів у різних регіонах України. Водночас їх проведення виявило затребованість хорового співу у широких колах, дозволило усвідомити великий потенціал професійного зростання та виявити лідерів у всеукраїнському масштабі. У цьому контексті винятково зростає роль хорового диригента, його особистої харизми, здатності згуртувати колектив довкола єдиної художньої мети, а також сформувати «свою» аудиторію, тонко відчути їі духовні потреби й запити. Талант диригента, його відданість хоровій справі обумовлює рівень популярності й значимості даного колективу в сучасному культурному середовищі. Саме такі колективи й стали візітівкою української культури: академічна хорова капела «Думка», львівський хор «Дударик», чоловіча хорова капела ім. Л. Ревуцького, Закарпатський народний хор, Буковинський народний хор, в останні роки - хори «Хрещатик», «Київ», а також колективи в регіонах «Кантус» 3 Ужгорода, хор ім. Д. Борт-нянського 3 Чернігова, «Легенда» 3 Дрогобнча та 5 багато ін. Проте в загальній яскравій і багатобарвній панорамі хорового мистецтва України один колектив займає особливе місце: це Національний заслужений академічний український народний хор України 
iм. Г. Верьовки. Окрему сторінку національної музичної історії вписав багаторічний художній керівник і диригент хору, Герой України, Лауреат Національної премії України імені Тараса Шевченка, народний артист СРСР та України, академік Національної Академії мистецтв України, академік Національної Академії педагогічних наук України, професор, Анатолій Тимофійович Авдієвський. Перейнявши після смерті засновника Григорія Гуровича Верьовки в 1966 році керівництво уславленим колекгивом, талановитий музикант не лише перетворив його в лабораторію дослідження української пісенної традиції, але й органічно вписавши діяльність народного хору в актуальний процес збереження і примноження національної духовності. Талановитий хормейстер, Анатолій Авдісвський одразу ж полонив і виконавців, і слухачів тільки йому притаманною творчою одухотвореністю, своєрідним відчуттям глибин і багатющих можливостей мистецтва хорового співу.

Робота 3 такими специфічними колективами - водночас і народними, i академічними, природно викликала особливий підхід, обумовлений необхідністю синтезувати кілька первинних пластів українського хорового співу [5, с. 396-397]. 3 одного боку, варто було спиратись на фольклорне виконання, яке характеризується передусім виробленою у давній традиції природною передачею як самого репертуару, так і манери співу від одного покоління до наступного. 3 іншого боку, фольклорну манеру в професійному колективі необхідно було сумістити 3 академічними засадами хорового співу, які в українській культурі теж мали багатовікову історію та величезні надбання.

Авдієвський ввів до складу хору академічні сопрано, завдяки чому значно розширився діапазон виконуваних творів та репертуарні межі колективу в цілому. Як по-новому зазвучали, заграли свіжими барвами «Щедрик», «Дударик», «Ой сивая зозуленька», настільки цікаво диригент використав темброву палітру xopy.

Потім була нова програма - цикл народних колядок і щедрівок, який розкрив перед слухачами неповторний світ наших звичаїв і обрядів. Після довгих років замовчування ці народні шедеври сколихнули слухачів не тільки в Україні, а й у багатьох країнах світу.

Так, Авдієвський у своій індивідуальній концепції інтерпретації української музики - передусім народних пісень, але й частково артефактів професійної національної музики - приходить до поєднання «грудного» регістру (як виразника народного співу) з поставленими вокальними голосами, що дуже збагачус барву звучання, надас ій неповторного звукового колориту й значної градації експресивних відтінків [6, с. 36-41]. 
Увесь виконавський процес хору ім. Г. Верьовки під керівництвом А. Авдісвського обумовлений його індивідуальною концепцісю національної природи хорового співу, в основі якого є впевненість у тому, що кожна нація має не лише свою оригінальну мелодичну та ритмічну першооснову в фольклорній спадщині, але й свій неповторний спектр звучання, тембральну колористику, яка $\epsilon$ похідною від фонетичного архетипу мови, втілена в народній музичній ритмоінтонації й становить 3 нею органічну цілісність, позначену й історичними алюзіями, і зверненням до фольклорної символіки. Для української духовності найбільшу цінність мають релігійні та паралітургійні жанри, давні обрядові пісні, пісні періоду визвольної боротьби, наприклад, стрілецькі.

Авторитет і велика популярність хору зумовлені поєднанням самобутнього стилю народного співу з високим професіоналізмом, безперервними пошуками нових мистецьких горизонтів, оновленням репертуару. Анатолій Тимофійович завжди прагнув до оновлення виконавеьких прийомів, розширення репертуару. Якщцо повернутись до перших новацій Майстра щодо виконавського стилю, то тембровий бік звучання народних пісень завжди цікавив митця. В одній з бесід Анатолій Тимофійович відзначив, «... кожна народна пісня, залежно від жанру, регіону побутування мас свої темброво-виконавські особливості [7]. Саме в попуку цього особливого звукового забарвлення кожної пісні, можливо, i криється секрет своєрідної, притаманної хорові виконавської інтонації. Надзвичайна природна музикальність Анатолія Авдієвського допомагає віднайти в звучанні хорових акордів властиве тільки його стилю виконання внутрішне емоційне наповнення. Акорди, по-особливому м'які та оксамитові, пронизуються народними відголосками, які виблискують особливим внутрішнім світлом і зачаровують своєю красою. Слухачі завжди пізнають звучання Народного хору, i це велика заслуга Маестро, що хор має своє виконавське обличчя, свій стиль.

Унікальністю художнього надбання Авдісвського в усіх його вимірах: диригентсько-виконавського, композиторського, педагогічного, просвітницького, організаційного полягає у виробленні ним особливої хорової інтонації, палітри звукотембрів, що об'єднує академічну та народну манеру звуковидобування в органічній цілісності.

Осмислюючи композиторський доробок Анатолія Авдієвського варто зазначити, що кожна народна пісня, залежно від регіону побутування й жанру, має свої темброво-виконавські особливості, тому композитор у копіткій щоденній праці пукав особливе звукове забарвлення кожної пісні, свій неповторний стиль, що вражас прозорою чистотою, граничною злагодженістю інтонування, м'якими й оксамитовими хоровими акордами, які зачаровують емоційно наповненим звучанням і рідкісною красою. 
Посднання грудної та академічної манери співу можемо окреслити як перший рівень синтезу у художньому ідеалі Анатолія Авдієвського. Таке прагнення до синтетичності виконання було відчуте й сприйняте диригентом як вагоме для українського ментального світовідчуття. Адже украӥнський фольклор за своєю природою послідовно синкретичний, $i$, міцно спираючись на обрядово-звичаєву основу, завжди спрямований на поєднання різних видів мистецтва в органічній цілості. Тому ідея синтетичності в представленні української художньої традиції завжди поставала як одна з основоположних у хорових дійствах, продуманих і підготовлених А. Авдієвським. Тому природним видається наступний рівень синтезу в його диригентському мистецтві: об'єднання пісні 3 усім обрядово-звичаєвим символічним комплексом, 3 танцювальною символікою, барвною колористикою декорацій та костюмів, що в естетичній свідомості нашого народу завжди були нерозривно поєднані в одну гармонійну цілість. Йдеться, зокрема, про послідовний «синкретизм» творчого доробку, тобто переінтонування кожного смислового елементу - чи то конкретного слова, чи підтексту, зашифрованого, передбачуваного при детальному вчитуванні в поетичний ряд народної пісні або в інтонаційному перевтіленні поезії сучасних авторів.

У руслі новаторської естетики «нової фольклорної хвилі», оновлення звукової палітри згідно вимог часу можна розглядати багато інтерпретацій Анатолія Авдієвського, завдяки яким сформувалась прекрасна традиція виконання багатьох пісень у постановці хору ім. Г. Верьовки, - тяжіння до єдності всіх елементів художньої цілості, що славетним колективом, насамперед, перевтілено 3 давніх фольклорно-обрядових традицій, 3 ритуального багатства й звичаєвої пам'яті нашого народу.

Величезний диригентський досвід Анатолія Тимофійовича Авдісвського дозволив йому переосмислити ментальні засади українського пісенного фольклору й кожного разу знайти відповідні засоби хорової фактури, гармонічного ряду, тембральної колористики, завдяки яким глибинна природа кожного пісенного зразка виявляеться максимально зближеною і підноситься у своій первозданності. Свій творчий досвід майстер виклав у наукових працях, збірках українських народних пісень та пісень народів світу. Як педагог підготував сотні музично-педагогічних працівників.

Народний хор ім. Г. Верьовки - це справжня Академія народного мистецтва. Хор, оркестр, хореографічна група, навчальна студія, ансамбль «Цвітень» - це справжнє сузір'я народних виконавців, яких дбайливо збирав і виховував Анатолій Авдієвський разом із своїми колегами - керівниками творчих груп. 
А. Авдієвський вів колектив невторованими стежками до нових звершень у сучасному хоровому мистецтві. Рідкісна багатогранність диригента й хормейстера, першокласного музиканта, композитора, неперевершеного майстра обробок народних пісень приносить світову славу його талановитому колективу, а разом 3 тим - українській пісні.

\section{Сшисок використаних джере.}

1. Горбатюк, В., Вишнева, А. Солов'їна домівка. Український народний хор / В. Горбатюк, А. Вишнева // Музика. - 2014. - № 4. - С. 4-11.

2. Драгомирецька О. Обробки пісень літературного походження Анатолієм Авдісвським: специфіка трансформації образного змісту // Українська культура: минуле, сучасне, шляхи розвитку. - 2012. - Вип. 18(2). - С. 138-142.

3. Зінченко Н. Анатолій Авдієвський: «Нашу країну зберегла музика» / Н. Зінченко // Музика. - 2011. - № 1-2. - С. 4-9.

4. Кияновська Л. Анатолій Авдієвський (До 75-річчя від дня народження) / Л. Кияновська // Актуальні проблеми мистецької практики і мистецтвознавчої науки. - 2009. - Вип. 2. - С. 67-69.

5. Корнійчук В. П. Маестро Анатолій Авдієвський. Портрет хору з мозаїки / В. Корнійчук. - Киӥв : Криниця, 2012. - 494 с.

6. Мартинюк А. Постать академіка Анатолія Авдієвського і обрії української музичної культури сьогодення / А. Мартинюк // Українознавчий альманах. - 2014. - №. 16. - С. 36-41.

7. Неділько С. Анатолій Авдієвеький: «Піснею можна оздоровити й очистити самих себе, землю, світ» [Електронний ресурс ] / С. Неділько. Режим доступу : https://ukurier.gov.ua/uk/articles/anatolij-avdiyevskij-pisneyumozhna-ozdoroviti-j-o/. - Назва з екрана.

\section{References}

1. Drahomyretska, O. (2012). Anatolii Avdiievskyi's interpretations of songs of literary origin: the specificity of transformation of imagery content. Ukrainska kultura: mynule, suchasne, shliakhy rozvytku. [Ukrainian culture: the past, the present, and ways of development], issue 18(2), pp. 138-142.

2. Horbatiuk, V., and Vyshneva, A. (2014). Nightingale's home. Ukrainian Folk Choir. Muzyka [Music], no 4, pp. 4-11.

3. Kyianovska, L. (2009). Anatolii Avdiievskyi (To the 75th Anniversary of Birthday). Aktualni problemy mystetskoi praktyky i mystetstvoznavchoi nauky. [Topical problems of artistic practice and art criticism], issue 2, pp. 67-69.

4. Korniichuk, V. (2012). Maestro Anatolii Avdiievskyi. Mosaic portrait of the choir. Kyiv: Krynytsia. 
5. Martyniuk, A. (2014). The figure of academician Anatolii Avdiievskyi and the horizons of the Ukrainian musical culture of our time. Ukrainoznavchyi almanakh. [Ukrainian Studies Almanac], no. 16, pp. 36-41.

6. Nedilko, S. (2016). Anatolii Avdiievskyi: «It is possible to heal and purify ourselves, the earth, and the world with the song». Available at: <https:// ukurier.gov.ua/uk/articles/anatolij-avdiyevskij-pisneyu-mozhna-ozdoroviti-j-o/> _Accessed on 10 September, 2016].

7. Zinchenko, N. (2011). Anatolii Avdiievskyi: «Our country was saved by music». Muzyka. [Music], no. 1-2, pp. 4-9.

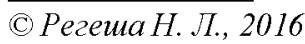

